\title{
Ymer-80, the Swedish Arctic Expedition 1980
}

\author{
Valter SCHYTT*
}

Adolf Erik Nordenskiöld's circumnavigation of Europe and Asia, including the first Northeast Passage, was considered one of the really outstanding achievements in the history of geographical exploration. Indeed, of such importance that your Geographical Society regards Nordenskiöld's voyage and his long and successful stay in your country, a worthy reason for a centennial symposium.

It is obvious that, in Scandinavia, Nordenskiöld is looked upon as one of the greatest representatives of Swedish and Finnish natural scientists-and not only among the scientists themselves but also among the educated laymen. It thus happened, that a little over three years ago a young Swedish naval officer was reading up on his polar history and, impressed by the Navy's contribution to polar exploration during the Vega voyage, he thought it an excellent idea to have the Navy return to the polar seas, this time to celebrate the centennial of the first Northeast Passage. He actually proposed to send an expedition onboard a Swedish state icebreaker along Vega's track along the Siberian coast to Bering's Strait, and then let her return home via Amundsen's old route from 1903-1906, the Northwest Passage, i.e. it would be the first circumnavigation of the whole Arctic Ocean-except for the short stretch along the north coast of Greenland.

The proposal was made 3 years ago, in 1976. Commander Daggfeldt had thought of 1979 as the proper year for the celebration-since the Northeast Passage was successfully completed in 1879-but that did not become possible.

The expedition will start in 1980 , and the route will be very different from the one originally proposed.

When Nordenskiöld planned his Vega voyage, things were not as complicated as they are today. His expedition was born on the 26th of January 1877 at a dinner at the Royal Palace in Stockholm. Nordenskiolld gave an account of the expedition's scientific programme and of how to carry it out-King Oscar was enthusiastic and promised to give all his support, and another guest, the very wealthy merchant Dr. Oscar Dickson promised economic contributions. Less than $1 \frac{1}{2}$ years later the expedition was ready to start. After Vega's return the King, Dr. Dickson and the Russian merchant Sibiriakoff paid one third each of the expedition costs. Good old days.

* Department of Physical Geography, University of Stockholm 
The organization of the centennial expedition has taken more time, difficulties have appeared that Nordenskiold could never have thought of. The original idea did not come from a scientist, but from a naval officer, and its main aim was a celebration. This would not have been quite realistic in Sweden of today. A circumnavigation of the Arctic basin involves such a tremendous effort in money, icebreaker time, scientists etc. that nothing but a very strong scientific programme can justify the expenditure.

Through the joint effort of The Royal Swedish Academy of Sciences, The Royal Society of Naval Sciences and the Swedish Society of Anthropology and Geography a committee was set up to try to organize the expedition and, based on 33 research proposals, received in February 1977, a strong, well-integrated scientific programme was worked out. The expedition was, at that time, named Ymer-79.

It is, however, not easy to run a scientific expedition along the Siberian coast without Soviet approval or cooperation. Since it was quite necessary for our geological programme to get sediment-cores from the bottom of the continental shelf all along the planned route, we had to receive proper permission from the coastal states concerned. The new international sea laws have greatly hampered the free scientific research.

We thus had to make some kind of a deal with Soviet. In Antarctica, as you know, the scientific cooperation is warm and friendly and quite open-very much due to the successful work of SCAR, the Scientific Committee on Antarctic Research. In the Arctic, however, the scientists have not been successful in organizing a similar cooperation. The distances between the great powers are short across the Arctic, and the strategic importance of the area is therefore considerable. Our Academy of Sciences informed the Soviet Academy about the expedition plans and proposed a Soviet-Swedish meeting for at discussion of a possible joint effort.

But we never got an answer, in spite of several measures taken by the Swedish Foreign Office. It finally became quite clear that Soviet did not want to permit a Swedish scientific expedition to go through her waters, or rather over her continental shelf.

Consequently we switched over to an alternative plan-named Ymer-80. We took this decision in May 1978 and thought time was too short for a start in 1979therefore Ymer-80. The working area for Ymer-80 was to be: the northern Barents Sea, the deep ocean north and northeast of Spitsbergen, the sea between Spitsbergen and Greenland, the waters and the ocean bottom outside north Greenland.

Even before I start to describe the scientific programmes planned for the ex- 


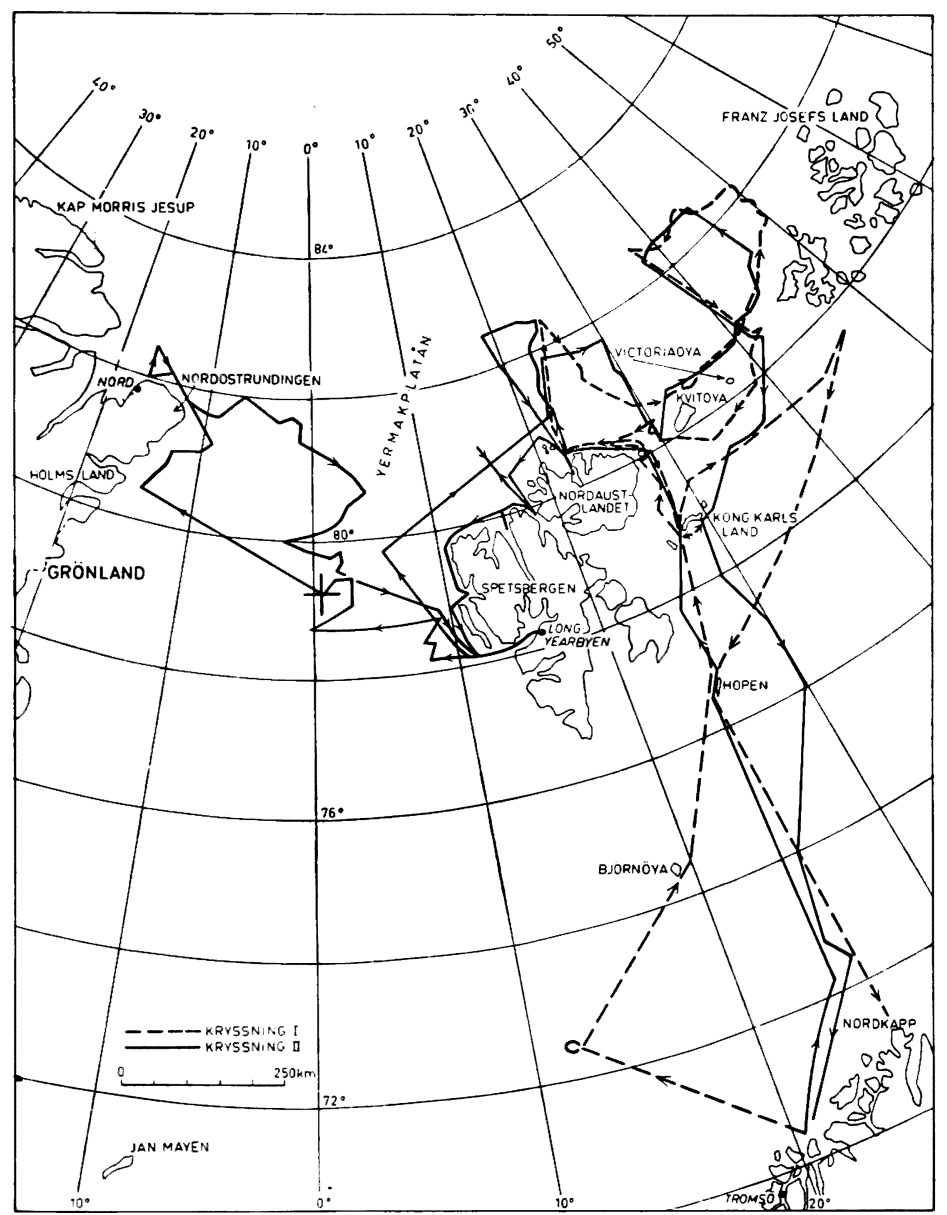

Fig. 1 Routes covered by Ymer during the summer of 1980 .

pedition, first for Ymer-79 and later for Ymer-80, I want to make it quite clear that the scientists involved do not look upon Ymer-80 as a less valuable alternative from a scientific point of view. For several of our projects it is rather the opposite. The originally planned expedition, the Ymer-79, would have had to follow a route parallel to the Siberian coast and. very likely, with very few perpendicular profiles. For studies of the marine sedimentation such, north-south, profiles are of course of greatest importance. And it is important, during a polar expedition, to adjust plans and routes according to results already gained. That would probably have been difficult along the Northeast Passage.

For Ymer-80, it is rather the opposite. In a very large and quite unexplored area we can pick those key localities, where we can expect to find the most interesting conditions or the most valuable samples. The key localities for the ocea- 
nographers, the sedimentologists and the geophysicists rarely coincide-but, now we can let them all choose-within limits.

A large Arctic expedition cannot be organized without considerable financial support from various sources. The research onboard is financed by the Natural Science Research Council and the State will carry the cost for the icebreaker and its crew, two helicopters, food, fuel, etc. The icebreaker chosen for the expedition will be the Ymer, $100 \mathrm{~m}$ long and with $22000 \mathrm{Hp}$. It belongs to the Swedish Administration for Shipping and Navigation, i.e. it is a civilian ship, but it will be manned by a naval crew of about 50 men. The Ymer was built for ice conditions in the Baltic, to keep all Swedish harbours open in the winter, but she has never been tested in the heavy polar pack-ice.

The scientific preparations are well under way. The responsibility for priorities and large scale planning rests on a scientific committee of 5 active scientists. They decided, $2 \frac{1}{2}$ years ago and at time for Ymer-79 along the Asiatic and American coasts, to give highest priority to the following main sectors of research:

1. Studies of the amount of pollutants in the Arctic atmosphere and studies of the influence of the Arctic stratus-cover on the heat balance of the ocean.

2. Studies of the extent and the chronology of the quaternary ice-sheets and of related climatic changes.

3. Studies of the biology of the Arctic Ocean with special reference to hte evolution of species brought about by the freezing over of the ocean at the end of Tertiary.

When it was decided to let the expedition work in the Spitsbergen-Greenland area, with the much greater ocean depths than along the continental shelf, oceanography was also included in the high-priority group.

Let me now give a short account of the more important projects which will be carried out next summer.

Scientists have now observed human pollution of the atmosphere from one pole to the other. In central Antarctica one can still find the snow of 1955 which was contaminated by radioactive fall-out from the nuclear bomb tests at Bikini-Eniwetok in March/April 1954. Studies of the lead content in the snow and firn on Greenland show a tremendous increase coinciding with the introduction of high-octane petrol on the American market, and the Arctic Research Laboratory at Barrow; Alaska, has observed high pollution values in winter-time. The source-area for these 
pollutants seems to be the highly industrialized areas in Western Europe and not those in Northeastern United States, in spite of them being much closer. Very little to find out what kind of damage different pollutants may cause in the Arctic environtions, their source areas and their chemical composition. It is also very important is yet known about the distribution pattern of these pollutants, or their time variament, which is still less influenced by human activities than most other parts of the world. But it is an extremely sensitive environment because of the cold climate. The pollutants may mean a deadly threat to life on the Arctic tundra and in the Arctic Ocean-we do not yet know-but they may also, if abundant in the Arctic atmosphere, change its radiation balance and thus affect the climate even on neighbouring latitudes.

During the whole journey, i.e. during July, August and September next year, the atmospheric chemists will analyze the air for gases such as sulphur dioxide, ozone, radon, carbon-14, carbon dioxide and several others. The particle size and chemical composition of aerosols will be studied with special interest.

Another important meteorological project will be based on land, at Kong Karls Land, a barren group of islands east of Spitsbergen proper. Dr. Holmgren of Uppsala will investigate the processes responsible for the cooling off during the summer of the lower air layers in contact with the pack-ice. This causes the high frequency of stratus clouds and of strong surface inversions. The stratus clouds influence the radiation balance and thus the general climate. For Dr. Holmgren the frequent stratus and ground fog will be welcome research objects; for us the fogs will only cause trouble.

The oceanographic programme has grown during the course of the planning. Ymer-79 was planned for work on the continental shelf-Ymer-80 will explore the deep ocean. Furthermore the oceanographic work is of great importance to both marine geology and marine biology. We will have physical as well as chemical oceanographers on board.

The only large connection between the Arctic Ocean and the other large oceans is the wide strait between Spitsbergen and Greenland. Large amounts of warm Atlantic water with high salt content flows north along the west coast of Spitsbergen, and at the same time a corresponding mass of cold, less saline Arctic water with lots of drifting sea ice flows south along the east coast of Greenland. This exchange of water has a clear climatic influence, and our oceanographers need information on temperature, salinity and currents down to great depths along many well selected profiles.

The chemical oceanographers will analyze the sea water's content of trace metals 


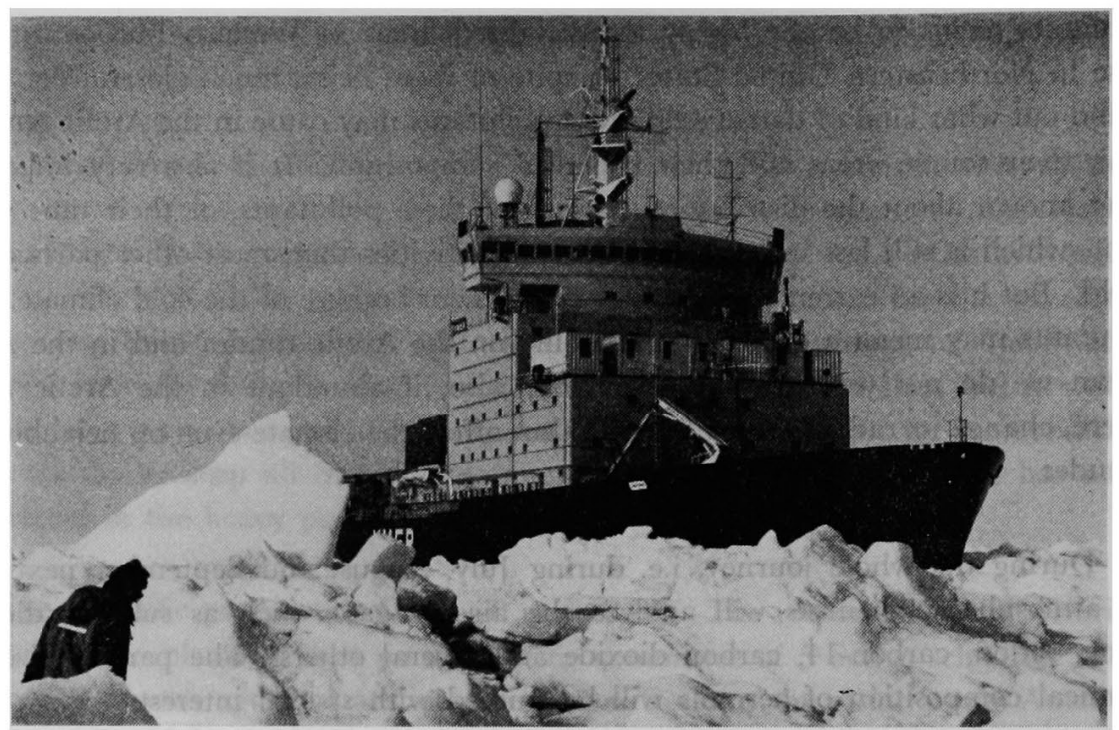

Photo 1 Ymer in heavy first-year ice. Ten well-equipped containers with good laboratory facilities were welded on to the decks, thus converting the icebreaker into a research ship.

hydro carbons, and long series of radioactive isotopes. Their results can be used for the studies of water currents in both vertical and horizontal direction. Some of these radioactive pollutant can, as you know, be used for scientific purposes. I just mentioned the radioactive snow in Antarctica, which tells the glaciologist how much snow has fallen after 1955, and provides the best means of measuring the annual rate of precipitation in the interior of the ice-sheet continent. In the same way the radioactive waste dumped in the sea from the atomic plant at Windscale in England can now be used as a perfect signal when studying water movements in the Arctic basin.

For our biologists, one central problem is the evolution of species in the Polar sea. It is well known that the global climate became colder and colder during the Tertiary. It was not a continuous cooling-but the general trend was towards a colder climate. The Arctic Ocean probably became ice-covered for the first time $15-20$ million years ago-some say only $3 \frac{1}{2} 2$ million years ago. We may be able to find the right answer next summer. One also knows when the strait between Spitsbergen and Greenland was opened up-at least approximately-and when there was a connection with the Pacific through the shallow Bering's Strait.

Our biologists look upon this tremendous change in environment-from a warm early Tertiary to a really cold ice age in Quaternary-as a gigantic experiment in evolution. Both the recent and the fossil fauna shall be studied-the geologists will be able to tell the biologists everything about how much time has been available 
for the evolution of new species or radical changes in others, and from their sediment cores they can interpret the changes in climate during this time span.

All marine life shall be studied, and since so little is known from the deep icecovered areas, we expect interesting results. Just as the meteorologists observe all pollutants in the air and the oceanographers in the water, the biologists will collect samples from birds, mammals, fish, plankton, bacteria and bottom-living creatures to see how the natural environment has been disturbed so far.

One fascinating branch of the biological programme will be the study the polar bear. Interesting not only for the scientists directly involved, but for all people on board. Polar bears are beautiful, particularly when seen from a ship's deck. If you meet him on land or on the sea ice, he may attack without warning. Several bears will be tagged-some of them will be marked with little radio transmitters, so that their tracks can be traced from a satellite. From conservation point of view it is important to know how far these bears move.

Certain biological projects will be carried out by a group based on Kong Karls Land-called the cradle, the birth-place, of the polar bear. They will have to keep a really good watch and never move around without a gun.

The extent of the Quaternary ice-sheets in the European Arctic has from the very beginning been looked upon as one of the most important questions for the whole expedition. How far did the ice-sheets reach during the different ice ages, did they reach their maxima at the same time as the Scandinavian ice-sheet, what were the climatic characteristics like in the Arctic during and between ice ages? During our expeditions in the area in 1957, -58, -65, -66, -67 and -69 we found evidence of considerable glacial retreat from Spitsbergen about 11.000 years ago. Sediment cores from inland lakes show the first sign of life at about that time, drift wood and dead whales drifted ashore on beaches which are now lying $60-80 \mathrm{~m}$ above the present sea level. We also found out that a particular beach, 61/27 thousand years old, marked by pumice that had drifted ashore after a volcanic eruption in the Arctic Ocean, or perhaps in Iceland, is situated at sea level in the north western corner of Spitsbergen and at $35 \mathrm{~m}$ elevation in the southeast. Our conclusion was, that an earlier inland ice-sheet had had its culmination over the Barents Sea-but we could never say, whether that ice-sheet had ever been connected with that over Scandinavia.

We want to concentrate our land-based studies this time on the eastern and southeastern islands, and one group of geographers and glaciologists will work with both the Pleistocene and the recent glaciation of Kong Karls Land. The frequent surface inversions permit glaciers to develop much below the expected glaciation 


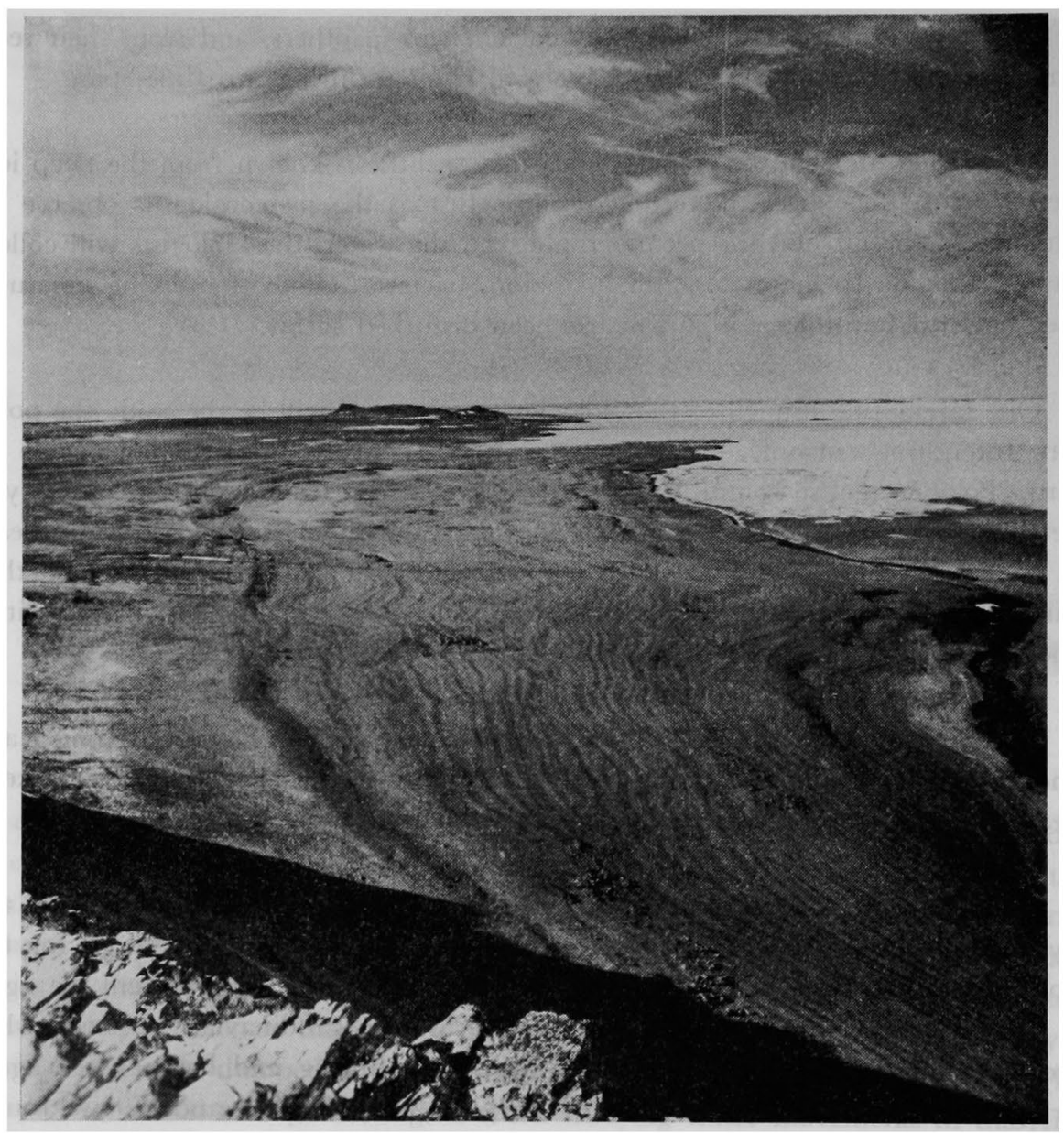

Photo 2 Raised beaches along the shore of Lady Franklin Fjord. The altitude, tilt and age of such beaches are parameters used for the study of glacial history.

level, and it is even possible that glaciers exist with higher ablation at high level and lower ablation near the sea. The net balance is, how ever, higher at the centre of the glacier than at its front.

I mentioned that we need to know about the possible connection between the large ice sheets in the European Arctic. We need this knowledge for further research on the development of global climate. No good models can be constructed if we don't know how large the ice and snow covered areas were during the ice ages. Better understanding of the conditions in the North is also important for other problems in the field of Quaternary geology-not least for the prospecting. 
We will have one group working with sediment cores from the bottom of the Barents Sea. The ice conditions are far better there than in the north, and therefore our scientists will be allowed to work from a smaller research ship run by the Norwegian Polar Institute, and we will provide facilities for about 10 Norwegian scientists to work from our ship in less accessible areas.

Several marine geologists and geophysicists on board will work with problems concerned with sediments on the continental slope and in the deep ocean. We hope to retrieve 15 to $20 \mathrm{~m}$ long sediment cores, and we should be able to get down into sediments at least a few million years old. They will reflect the climatic development and the extent of Pleistocene ice-sheets. The movement of the continents, the volcanic history of the spreading centres will also be studied.

On the 25th of June we plan to start from Sweden and by then the ice-breaker should be equipped with all those instruments necessary on board an advanced scientific research ship.

We will first run a test cruise in the deep ocean outside the Norwegian coast and then put ashore about 20 scientists on Kong Karls Land. July and the early part of August will be devoted to cruises into the Arctic Ocean east and northeast of Spitsbergen. During this part of the voyage there will be 18 biologists on board and hardly any earth scientists; biology will have highest priority. On the 8th of August the expedition will return to Tromsö, to refuel, to leave most of the biologists and take on board 12 geologists for the next expedition leg. We will return to the Spitsbergen waters and its interesting island cross over towards Greenland at the end of August for work along the north coast where no ship has ever been before. Northern Spitsbergen will be visited also in September and we hope to return to Sweden before 1 October.

The total scientific staff, on board and on land, will be about 85 scientists, 30 of them from outside Sweden. Scientists from at least 8 nations will take part. Nearly 20 professors will be on the staff--so we hope that the expedition shall be a worthy way of celebrating A. E. Nordenskiöld's famous journey with the Vega.

P.S.

The above lecture was given in November 1979. The expedition sailed from Stockholm on 24 June 1980 and returned on 1 October.

All the work outlined above was carried out-only minor details were changed. 119 scientists and technicians from 9 different nations were engaged onboard the Ymer and on the Arctic islands. Oceanographical, biological and geological samples 
were taken from the continental shelf out to $4000 \mathrm{~m}$ depth on the Arctic abyssal plain.

$$
\text { イーメル80-1980年に行われるスウェーデンの北極探検 }
$$

$$
\text { ヴァルテル・シット* }
$$

スウェーデンでは，100年前になされた A. E. ノルデンショルドによるユーラシア周航という 地理学上の偉業を祝福すべく, イーメル80といら名で, 北極探検が計画されている。調查には, 砕氷船イーメル（全長 $100 \mathrm{~m}, 22,000$ 馬力）のほか, ノールウェイ極地研究所の調查船, ヘリコプ ター 2 機等が参加する。イーメルの航行ルートは地図に示すとおりである。調査は陸上でも行わ れる。本計画の前に，イーメル79と称して，主としてシベリアの海岸に平行に航行する1979年実 施の計画が立てられたが，ソ連の協力が得られなかったこともあり中止となった。しかし，科学 的な価值は本計画の方がむしろ上である。この探検での研究の対象は多岐にわたる。気象学の部 門では，大気中の污染物質（気体，エーロゾル，放射性同位元素等）や流水と接する気層の夏期 の泠却およびそれに関係する層雲や霧の発生などについての調查が行われる。海洋学の部門では, まずは, 北極海をめぐる水の交換とその気候への影響, 海水の動き, さらには海洋污染などを究 明すべく, 海洋物理学と海洋化学の立場からの調查が行われる。本探検での生物学上の中心的プ ログラムの一つは, 北極海における種の進化である。生物学者は, 地質学者の協力を得て, 温暖 な第三紀初期から第四紀の氷期にかけて，環境と時間と種の進化の関係について考察する。さら に, 厚い水にお扔われた地域での海洋生物や環境破壊の実態を究明すべく, 数多くの生物の標本 を集める。また, 生物学の魅力的な分野の一つとして, 北極熊の生態の調查も行われる。地理学 者, 氷河学者は, コングカールスランドでの更新世および現世の氷河作用について研究すること になろう。接地逆転と氷河の消長の関係についても研究がなされる。地球的規模での気候変化の 研究がさらに前進するためには，ヨーロッパ北極での氷床の可能なつながりを知る必要がある。 バレンツ海では，海底堆積物のコアが採取される。さらに何人かの海洋地質学者と地球物理学者 は，大陸斜面と深海底の堆積物に関する問題に取り組む。15 20m のコアが回収されることが望 まれる。少なくとも数百万年前までの 堆積物を調べられることが必要である。このような堆積物 は，気候変化と更新世の氷床の広がりを反映するであろう。さらには，大陸移動や火山活動の歴 史も研究されることになろう。

\section{追記}

船は1980年 6 月 24 日にストックホルムを出航し同年10月1日に帰港した。すべての作業は細部 を除いて計画どおりに進められた。この探検には，9カ国より119人の科学者と専門技術者が参加 した。

(徳永英二)

\footnotetext{
*ストックホルム大学自然地理学教室
} 